\title{
Forklaring eller forklarelse
}

\section{Om Udødeligheden af Milan Kundera}

\section{Kunderas roman(poe)tik}

Er der noget, Milan Kundera ikke kan fordrage, er det den tyske romantik. I Udødeligheden sætter han nogle af epokens skikkelser i scene som romanpersoner, først og fremmest den store Goethe, som har al hans sympati, hvilket ikke kan siges om hans kvindelige modspiller: Bettina von Arnim, der hører til »den bande romantikere med blege ansigter, der hen imod slutningen af hans [Goethes] liv havde bemægtiget sig Tyskland. « Kunderas holdning til generationen af unge romantikere (»netop den, der udmærkede sig ved romantik og briller«, p. 60) er helt solidarisk med Goethe, som ikke har »den ringeste sympati« herfor (p. 76).

Ikke nok med at romantikerne har blege ansigter og går med briller; de har det også med at svømme hen i eskapistiske drømmerier om transcendens og død:

„De var blændet af døden fra det øjeblik, de første gang så verdens lys. Novalis nåede ikke at blive tredive, og alligevel, på trods af at han var så ung, var der aldrig noget, der inspirerede ham som døden, troldkvinden døden, døden transformeret til poesiens alkohol. Alle levede de i transcendens, gik ud over sig selv, rakte armene ud i det fjerne, helt ud til afslutningen af deres liv og langt ud over deres liv, ud i ikke-værens fjernhed«(p. 81).

Kundera kobler sig således på det konventionelle billede af romantikken som en beruset verdensflugt. Endvidere karakteriseres romantikerne - gennem Bettinas repræsentative figur - som selvforherligende og sentimentale; de

1. Der citeres efter Milan Kundera: Udødeligheden, på dansk ved Eva Andersen, Kbh. 1990, p. 103. Hvis ikke andet er anført, gælder sidehenvisningerne herefter denne udgave. 
blæser sjælen op som en ballon og sætter sig i scene på den mest affekterede vis, de guddommeliggør historien og savner enhver jordforbindelse.

Det er imidlertid min påstand, at Udødeligheden på to måder selv knytter an til romantikken. For det første er romanen i sin ironiske, paradigmatiske og heterogene form ganske kongenial med en side af den tidligtromantiske poetik, som Kunderas romantikkritik er blind for. For det andet rummer romanens heltinde Agnes (som udsigelsesmæssigt står fortælleren meget nær, hvilket i det følgende vil blive påvist) en længsel, der ifølge Kunderas eget eksplicitte romantikbillede må karakteriseres som romantisk - en længsel efter natur og transcendens og måske i sidste ende død.

Den romantiske romanpoetik, som man finder den i Friedrich Schlegels og Novalis' fragmenter, fejrer romanen som en ironisk og selvsættende blandingsgenre. På det tidspunkt hvor Schlegel og Novalis skriver deres fragmenter (omkring år 1800) er romanen stadig en bastard i genrernes rige: den kan ikke indordnes under nogen af de klassiske genrer; den er hverken epos, lyrik eller drama. Derimod kan den indoptage elementer af forskellige genrer i sig, og det gør den i høj grad i Schlegels og Novalis' samtid: tænk bare på Goethes Wilhelm Meister, som har indlagte digte, noveller, breve og dagbogsoptegnelser! Romantikerne anskuer denne heterogenitet, denne genremæssige åbenhed og frihed, som en kunstnerisk kvalitet, men betoner samtidig nødvendigheden af at den enkelte roman så meget desto mere former sig selv i fasthed: at der ikke foreligger en på forhånd faststøbt genreform, betyder ikke at den enkelte roman bliver formløs, men at den så meget desto fastere må sætte sit eget formprincip og udfolde det konsekvent. »Dannelsen« i »dannelsesromanen« hentyder for de tidlige romantikere ikke så meget protagonistens dannelse som romanens egen formdannelse.

I og med at romanen sætter sig selv, er den en fundamentalt (selv)refleksiv genre. Og dermed også en ironisk genre. For de tidlige romantikere er ironien selve refleksionens dynamik: det at man må hæve sig over sig selv for at sætte sig selv. Schlegel definerer ironien som en dynamik af »selvskabelse og selvtilintetgørelse ${ }^{2}{ }^{2}$ og hermed er ironien strukturelt beslægtet med romanformen, der på én gang er selvudvidelse og selvbegrænsning. Således skriver Walter Benjamin i sin bog om den tidligtromantiske romanpoetik:

"Blandt alle fremstillingsformer findes én, i hvilken romantikerne finder, at den refleksive selvbegrcensning såvel som også selvudvidelsen er

2. Friedrich Schlegel: Kritische Friedrich Schlegel-Ausgabe, Bd 1-19, udg. Ernst Behler, Paderborn/München/Wien 1958-1981, Bd 2, p.172 
udviklet på det bestemteste, og at de på denne tinde går forskelsløst over i hinanden. Denne højeste symbolske form er romanen. ${ }^{3}$

Benjamin argumenterer videre for, at denne særlige refleksive dynamik i romanformen betyder, at romanen har ironien »i sin forms natur«, altså som et formelt væsenstræk og ikke som en bevidst fortællerstrategi. I denne definition af den romantiske roman-ironi adskiller Benjamin sig fra Ingrid Strohschneider-Kohrs, der i sin glimrende Die romantische Ironie in Theorie und Gestaltung definerer ironien som bevidst metafiktion gestaltet efter fiktionens principper. ${ }^{4}$ For Strohschneider-Kohrs er den romantiske ironi en bevidst fortællerstrategi, hvori fortælleren eller det fortællende lag i teksten gør eksplicit opmærksom på sig selv, men samtidig indskrives som en del af fiktionen. I Benjamins opfattelse er den romantiske ironi et formtræk ved romanen; en ironi der ligger immanent i spændingen mellem dens fortællende niveauer, uden at denne spænding nødvendigvis skal fremhæves eksplicit i teksten. Vi skal se hvordan begge typer ironi er at finde i Kunderas roman: på den ene side ironien som den fiktive gestaltning af det fortællende niveau, på den anden side ironien som en ikke-ekspliciteret gnidning mellem forskellige udsigelseslag.

For de tidlige romantikere er romanen endvidere hvad man kunne kalde en musikalsk genre. I sit essay om Goethes Meister griber Friedrich Schlegel til musikalske metaforer for at beskrive værkets komposition. Som påpeget af Winfried Menninghaus er Schlegels ærinde at flytte opmærksomheden fra romanens semantiske udsagn til dens æstetiske formdannelse, og her kan de musikalske termer hjælpe ham, fordi de er hentet fra en kunstart, hvis materiale ikke har samme semantiske binding som litteraturens. Sammenligningen med musikken tvinger opmærksomheden bort fra værkets semantiske udsigelse og over mod dets kompositorisk-strukturelle dimensioner, ordene bliver til materiale i en kunstfærdig formgivelse fremfor primært at være leksikalske størrelser med en vis indholdssubstans. ${ }^{5}$

Sammenfattende kan man sige at romanformen for de blege og bebrillede romantikere er karakteriseret ved at være ironisk, autonom, heterogen og musikalsk. Det er pudsigt nok de samme prædikater, den romantikhadende Kundera selv tildeler romanformen i essaysamlingen Romankunsten. Her defineres romanen som den »den ironiske kunstart«; dens ironi er af »konsubstantiel« art, dvs. et objektivt formtræk ved roman-

3. Walter Benjamin: Der Begriff der Kunstkritik in der deutschen Romantik (org.1920), Frankfurt a.M. 1973, p.92; mine fremhævelser.

4. Ingrid Strohschneider-Kohrs: Die romantische Ironie in Theorie und Gestaltung, Tübingen 1960.

5. Winfried Menninghaus: Unendliche Verdopplung, Frankfurt a.M. 1987, p.176. 
genren som sådan. ${ }^{6}$ Endvidere insisterer Kundera på at romanen er »radikalt autonom «og kun som sådan kan producere sandhed. ${ }^{7}$ Endelig bestemmer Kundera romanens form som "polyfonisk« og griber hermed til en musikalsk metafor for at beskrive romanens heterogenitet. »Polyfonisk« er romanen for Kundera, fordi den er i stand til at sammenflette ikke bare forskellige stemmer eller historier, men også forskellige genrer. ${ }^{8}$ Denne sammenblanding af forskellige genrer er ifølge Kundera en fornyelse af romanen, som vi kan takke Hermann Broch for; i Brochs Schlafwandler blandes roman, novelle, reportage, digt og essay, og Kundera betegner dette som »Brochs revolutionerende nyskabelse «. ${ }^{9}$ Men denne romanens genreblanding er lige så lidt en fornyelse, som Kunderas romanpoetik er en nyhed; begge dele findes præformeret i den tidlige tyske romantik.

Vi skal i det følgende se, hvorledes - og hvorvidt - Romankunsten s i bund og grund tidligtromantiske romanpoetik indløses i Udødeligheden.

\section{Fortælleplaner og -positioner}

Der findes overordnet tre fortalte niveauer i Udødeligheden. På det første optræder Kundera selv, af og til i selskab med én af sine romanpersoner, Professor Avenarius. Ved at iscenesætte sin fortæller som person (der oven i købet bærer forfatterens navn!) lever romanen op til Strohschneider-Kohrs' definition af den romantiske ironi som fiktionens selvrefleksion gestaltet efter fiktionens egne præmisser. På romanens andet bevæger de utvetydigt fiktive romanpersoner sig. Disse to planer er nutidige, hvorimod det tredje plan er skudt 200 år tilbage i tiden og har historiske personer som aktører, først og fremmest Johann Wolfgang Goethe og Bettina von Arnim.

Udødelighedens planer knyttes overvejende paradigmatisk sammen, dvs. de gennemløbes ikke af samme plot, men forbindes af samme tematik. Et sådant paradigmatisk fremfor syntagmatisk kompositionsprincip har romanpoetikeren Kundera selv tilsluttet sig eksplicit i L'art du roman: „Dog tror jeg, der eksisterer noget dybere [end handlingens enhed], som sikrer romanens sammenhæng: den tematiske enhed. $\aleph^{10}$

6. Milan Kundera: L'art du roman, Paris 1986, p.164

7. Ibid. p. 145

8. Man kunne tro, at Kundera havde hentet sit polyfoni-begreb hos Mikhail Bakhtin, men det er ikke tilfældet, og selv om de to herrers begreb om romanens polyfoni nok er beslægtede, er de ikke analoge

9. Ibid. p.97

10. Ibid. p. 106 
Ved siden af de fortalte niveauer, som alle er »romaneske«, i den forstand, at de iscenesætter en række halv- eller helfiktive personer, findes et fjerde plan i romanen, som er typisk for Kundera, hvor forfatterrefleksionen uden at lægges i munden på den iscenesatte Kundera-person - breder sig ud og bliver til hele kapitler; et essayistisk plan. Det er ikke mindst denne refleksion og essayisme, som får Kundera-hadere til at hade Kundera, anse ham for kold og kynisk og alt for intellektuel til at skrive romaner. Det er imidlertid min mening, at disse Kundera-hadere læser Kundera alt for alvorligt; hans refleksioner er ikke systematiske intellektuelle operationer, men snarere løsslupne tankeeksperimenter, som er lige så legende og associative som et lyrisk digt. I Romankunsten taler Kundera selv om »det specifikt romaneske essay«, som er karakteriseret ved at være hypotetisk, provokatorisk - og aldrig alvorligt. ${ }^{11}$ De essayistiske refleksioner i Kunderas romaner har med andre ord nogle afgørende littercere kvaliteter og hører mere hjemme i romanen end noget andet sted.

De der kritiserer Kunderas essayistiske romaner for ikke at være litterære eller poetiske nok (f.eks. Jens Christian Grøndahl) ${ }^{12}$ får svar på tiltale i Romankunsten: „Men at tage poesiens krav på sig er noget helt andet end at lyrisere romanen (give afkald på dens essentielle ironi, vende sig bort fra den ydre verden, forvandle romanen til personlig betroelse, overlæsse den med ornamenter) «. ${ }^{13}$ Det æstetiske formdannende arbejde behøver ikke at ligge i en lyrisk udfoldelse af sprogets mikrostrukturer; for Kundera ligger det snarere i en krystalklar stil og en arrangering af værkets større enheder (dets forskellige fortalte planer og udsigelsesniveauer) i en nærmest musikalsk komposition.

Den eksplicitte fortæller, der bærer samme navn som forfatteren på romanens omslag: Kundera, situerer sig fra starten som en olympisk, altoverskuende fortæller. Han befinder sig højt hævet over byens tage, dasende $\mathrm{i}$ et motionscenter, "hvorfra man gennem store vinduer har udsigt over hele Paris«( $A d R$, p. 9). Fra denne priviligerede udsigtsposition styrer han sin fiktion. Visse af hans fiktive personer når dog op i samme højde: Først Agnes, som han i 3. kapitel lader stige op i samme motionscenter, hvilket kan ses som en angivelse af, at hun står temmelig højt i perspektivernes hierarki. Siden naturligvis Professor Avenarius, som hele tiden pendler mellem Kunderas og romanpersonernes niveau. Og til allersidst: Paul og Laura, som dog ikke herved får del i det olympiske perspektiv, men måske snarere er tegn på, at dette nu invaderes nedefra, at det er slut med den

11. Ibid. pp. 102-103.

12. Jens Christian Grøndahl: „Overflødighedshorn«, Vinduet 4 (1991).

13. L'art du roman, p. 178, herefter forkortet $A d R$. 
olympiske fortællers priviligerede position, ja med hans fortælling overhovedet. Nu må han selv ned på gaden og leve det liv, han så klartskuende har malet for os. (Én gang tidligere har vi set den olympiske fortæller stige ned: nemlig i den del, hvor Agnes dør. Som om han her nærmer sig sin personverden, bliver mere med-følende, mister lidt af sin suveræne kontrol over et stof, der uafværgeligt bevæger sig mod en død, som han ikke kan lide.)

Den olympiske er imidlertid kun én af to fortællerpositioner, som angives i første del. I den anden er fortælleren fjernt fra sin olymp, det altoverskuende klarsyn er afløst af en halvvejs bevidstløs tilstand. I starten af andet kapitel ligger han i de tidlige morgentimer i en tilstand mellem søvn og vågen, som beskrives således:

»Det er det smukkeste afsnit af søvnen, den lifligste del af dagen: takket være radioen opfatter jeg min ustandselige indsoven og opvågnen, denne herlige gyngen mellem vågen og søvn, der i sig selv er tilstrækkelig årsag til, at man ikke beklager sin fødsel« $(A d R$, p. 11).

Denne næsten proustianske fortællerposition - og den store værdi, tilstanden tillægges - er ganske overraskende, Kunderas sædvanlige lysvågne og meget bevidste kontrol over sin fortælling taget i betragtning. Det er som om, han her angiver en anden kilde til fortælling, som må arbejde sammen med den lysvågne og klartskuende refleksion, før historien kan gå i gang.

\section{Det tilfældige jeg}

Romanens hovedperson, Agnes, fødes i et samspil mellem de to radikalt forskellige fortællerpositioner: det klare overblik og den grumsede zone mellem søvn og vågen. I 1. kapitel opstår idéen til hende af en gammel dames gestus, som den klartskuende fortæller skarpsindigt observerer. I 2. kapitel vågner hun til live af den halvslumrende tilstand, som fortælleren overfører fra sig selv til hende:

"Da jeg vågnede, var den næsten halv ni, og jeg forestillede mig Agnes. Hun lå ligesom jeg i en bred seng. Den højre side var tom. Hvem mon hendes mand var? Åbenbart én, der gik tidligt hjemmefra lørdag morgen. Derfor var hun alene og gyngede sødt mellem opvågnen og drøm.

Så stod hun op« $(A d R$, p. 12n-13ø).

Hermed er fra starten angivet en nærhed mellem fortællerens og Agnes' position. Direkte sammenligning forekommer («ligesom jeg«), og som Kun- 
dera vågner af sin halvslummer for at fortælle, vågner Agnes for at blive fortalt. I 2. kapitel deler fortæller og Agnes således tilstand, og i 3. kapitel deler de sted, idet Agnes som nævnt stiger op til motionscenterets olymp.

Hvis man hopper udenfor romanens rammer og rundt i Kunderas andre tekster, findes der yderligere et vigtigt træk, som forbinder Agnes og Kundera (ikke så meget den eksplicitte Kundera-person, der vader rundt i Udødeligheden, men romanforfatteren Kundera i det hele taget.) Agnes grundlæggende problem er nemlig det, at hun betvivler det individuelle, unikke »jeg«, som er en grundpille i vor moderne europæiske kultur. For hende har dette »jeg« ingen substans, men består udelukkende af en samling tilfældige attributter. Problematiseringen af jeg'ets individualitet er ikke bare Agnes' hovedanliggende, men ifølge Kunderas L'art du roman også romanforfatterens:

"Alle romaner til alle tider hænger ved jeg'ets gåde. Lige så snart man har skabt et imaginært væsen, en romanperson, konfronteres man automatisk med spørgsmålet: Hvad er jeg'et? Hvordan kan jeg'et gribes?» (AdR, p. 39)

Selv regner Kundera i Romankunsten idéen om det unikke jeg for »en af de smukkeste europæiske illusioner« $(A d R$, p. 23) og beskriver sin egen holdning til jeg'et som en »forbløffelse over for jeg'ets uvished og identitet« $(A d R$, p. 45). Som betvivler af det unikke jegs sikre identitet deler Agnes altså problem med romanforfatteren Kundera.

Lad os følge Agnes' tilblivelse trin for trin:

Først er der en gammel kvinde. Af denne kvinde frigøres en gestus, og af denne gestus opstår et navn: Agne. Men kan en gestus og et navn være en persons væsensgrund? Til dette spørgsmål svarer romanen selv nej. Hverken gestus eller navn er individets unikke vandmærke. Ganske vist mener fortælleren i starten, at den gamle dames gestus blotter hendes »essens«, men han dementerer snart sig selv:

"Ja, sådan havde jeg opfattet det i et øjeblik, men jeg tog fejl. Bevægelsen [gesten] blottede ingen essens af denne dame, man kunne snarere sige, at damen havde ladet mig erfare ynden ved en bevægelse. Man kan nemlig ikke regne en bevægelse for et individs udtryk, for dets skaberværk (for intet menneske er $\mathrm{i}$ stand til at skabe sin helt originale og kun dette væsen tilhørende bevægelse [gestus]), ja, ikke engang for dets redskab; tværtimod er det snarere bevægelserne, der bruger os som deres redskaber, bærere, personificeringer« $(A d R$, p. 14). 
Gesterne bliver således overindividuelle størrelser, der næsten kan se ud til at høre hjemme i idéernes verden, og af hvilke det enkelte menneskes kropslige udtryk blot er en manifestation.

Agnes står endnu en gang fortælleren nær ved at have gjort en lignende erfaring af gesternes overindividuelle karakter. Men hun løfter dem på ingen måde op i en idésfære - tværtimod nedgør hun dem som tilfældige attributter:

»Da hun så sin bevægelse [gestus] udført af søsteren, der fra sin tidligste barndom havde beundret og efterlignet hende i et og alt, fornemmede hun en slags ubehag: den voksne bevægelse [gestus] passede ikke til den elleveårige lille pige. Men især slog det hende, at denne bevægelse [gestus] var udleveret til brug for alle, og at den følgelig ikke tilhørte hende: når hun vinkede med hånden, gjorde hun sig egentlig skyldig i tyveri eller falskneri« $(A d R$, p. 49).

Hverken for Kundera eller Agnes er gesten altså et nødvendigt tegn på irreducibel individualitet. Men dér hvor Kundera ophøjer gesten til selv at være en slags irreducibelt individ, forkaster Agnes den som tilfældigt attribut. Dette er Agnes' problem: hun orker ikke at bære rundt på de tunge tilfældigheder, der udgør jeg'ets fiktion: gesten, ansigtet - og navnet. Om navnet siger hun:

"Vores navn har vi også fået ved en tilfældighed « fortsatte hun. »Vi ved ikke, hvornår det er opstået, og hvordan en fjern forfader er kommet på det. Vi forstår overhovedet ikke vores navn, vi kender ikke dets historie, og alligevel bærer vi det med eksalteret troskab, smelter sammen med det, kan lide det, er latterligt stolte af det, som om vi selv havde fundet på det i et øjeblik af en slags genial inspiration.[...]«(AdR, p. 44)

Selv hedder Agnes Agnes med nødvendighed - det navn og den gestus, hun nægter at tage til sig som tegn på hendes unikke individualitet, er hendes væsensgrund som fiktiv romanperson.

I fiktionens verden er det således muligt at omvende det beklagelige forhold mellem attribut og kerne, som tynger Agnes. Jeg'et kan stå i et nødvendigt forhold til de attributter, det ellers må slæbe på som tyngende tilfældigheder, der udstyrer det med en vilkårlig identitet. Derfor kan Kundera mene, at en romanperson »i endnu højere grad« end et menneske er »defineret som et enestående, uigentageligt væsen« (p. 13). (I romanen bliver gesten i høj grad individets »skaberværk« og »redskab« - måske ikke det fik- 
tive individs, der udfører den, men den skabende forfatters.) Den unikke individualitet, som er en fiktion i realiteten, bliver til realitet i fiktionen.

\section{Væsensgrund eller billedserie?}

"Kundera« forklarer et sted i romanen Professor Avenarius, at enhver af hans romanpersoner har en væsensgrund. En typisk kunderask tanke, som man genkender fra L'art du roman, hvori det hedder:

"At gribe et jeg, det vil i mine romaner sige at gribe essensens af dets eksistentielle problem. Gribe dets eksistentielle kode«(AdR p. 46).

Det, Kundera i Romankunsten kalder en "eksistentiel kode«, betegnes i Udødeligheden med det gode germanske ord »Grund « (p. 271), og hvor den eksistentielle kode i Romankunsten har karakter af en serie nøgleord (eller nogle få situationer eller motiver), ${ }^{14}$ har denne »Grund« i Udødeligheden »karakter af en metafor».

Imidlertid nøjes fortælleren sjældent med at angive én Grund, ét billede for sine personer, men snarere en hel serie. Således fødes Agnes nok af den gamle dames gestus, men der kommer flere billeder i løbet af romanen: Agnes, der stopper fingrene i ørene ved vejarbejdets larm, mini-Agnes, der ved faderens side hopper afsted i takt med Goethes digt, Agnes, der går gennem byen med en blå forglemmigej, Agnes, der i ekstasens øjeblik ægges ved synet af sin nøgne krop i spejlet, Agnes, der ligger ved alpekilden og bliver til ren væren - og endelig de billeder, der dannes i en anden romanpersons (Rubens') hovede: Agnes som middelalderlig lutspillerske, Agnes som kvindelig og masochistisk nydende Jesus i korsfæstelsens øjeblik, Agnes som lig i flammerne. Det ser således ud til, at der ikke findes én »Grund « for Agnes, men snarere en ophobning af billeder. Eller en "serie af suggestive billeder" for nu at citere Kundera selv (p. 134). Disse suggestive billeder tillægges ganske vist den moderne medieverdens forargelige »imagologer«, men spørgsmålet er, om Kundera ikke også selv i sin billedophobning i så fald må siges at gå »imagologisk« til værks. Den suggestive billedserie er både de moderne mediers absoluterende massebedøvelse - og romanforfatterens relativerende kredsen om en eksistentiel mulighed; en modernitetens form, der - som så mange andre figurer i Udødeligheden - er tvetydig, både kan forherlige moderniteten og vende sig kritisk mod den.

14. Ibid. pp. 46 hhv. 53. 
Den ekspliciterede Kunderaperson har med sin tale om »Grund « en drøm om at finde det ene billede, den ene metafor, der kan rumme essensen af et helt individ. Romanforfatteren drømmer om at blive poet. Men den Kundera der skriver Udødeligheden, gør i stedet det, at han optrevler et billede (bold-gesten), decentrerer og varierer det, forskyder det i en serie af andre billeder, lader prosaens strøm skylle igennem det og rive det med sig.

Personen »Agnes« skabes således af en lang serie billeder. Et af disse er Agnes' eget drømmebillede af sig selv gående gennem Paris med en forglemmigej foran ansigtet, så storbyens grimhed skjules for hendes blik bag den "smukke blå prik« (p. 29). Denne fantasi får lov at slutte hele romanen af: da Kundera til allersidst er steget ned til byens gader fra det olympiske motionscenter, minder han os om Agnes' forglemmigej og sender hermed en sidste solidaritetshilsen til sin heltinde. Den blå blomst bliver endnu et knudepunkt, hvor Agnes, Kundera og den tidlige tyske romantik mødes.

Forglemmigej'en repræsenterer også et møde mellem tysk og fransk litteratur. Ikke alene blomstrer den i Novalis' Heinrich von Ofterdingen, den sidder også i hatten på en meget kendt dame i den franske litteratur: selveste Madame Bovary. ${ }^{15}$ Noget kunne tale for at læse Agnes som Kunderas bud på en moderne Mme Bovary-figur, som ganske vist valoriseres anderledes og mere positivt end den flaubertske: som påvist står Agnes meget nær fortællerens position, mens fortælleren hos Flaubert har en (omend af og til gennembrudt) distance til sin heltinde. Både Agnes og Emma er utilpassede romantiske sværmere, begge elskes af deres mænd med en naiv kærlighed, de ikke kan gengælde, begge bærer - eller drømmer om at bære - den blå blomst, forglemmigej'en, som et skønhedens værn gennem den hæslige verden. Men så hører ligheden også op. Mme Bovary drømmer om at stråle guddommeligt i sin unikke individualitet, som en romanheltinde - at nogen skal tilbede og forherlige hendes særlige »jeg«, hendes særlige ansigt. Om Madame Bovary skriver Kundera selv i L'art du roman:

"Den ydre verdens tabte uendelighed erstattes af sjælens uendelighed. Den store illusion om, at individet er enestående og uerstatteligt, en af de smukkeste europæiske illusioner, folder sig ud«( $A d R$, p. 23).

15. F.eks. Léon til Emma: »Vous aviez même un chapeau à petites fleurs bleues«. Kort før dette sted taler Léon endog om samme slags blå blomst, som den Agnes vil bære frem for sig som værn mod byens grimhed: forglemmigej'en, eller som den så smukt hedder på fransk: "le myosotis«. Léon har set den i en muses hår på et kobberstik og fortæller Emma om den: "Elle est drapée d'une tunique et elle regarde la lune, avec des myosotis sur sa chevelure denouée. (...) Elle vous ressemblait un peu«. Gustave Flaubert: Madame Bovary, Paris, 1961, pp.217-219. 
For Kundera repræsenterer Madame Bovary altså netop den (illusoriske) forestilling om det unikke, uforlignelige individ, som har præget den europæiske (roman)historie gennem de sidste par århundreder. Med sin moderne Emma Bovary-figur, Agnes, lader Kundera denne historie beskrive en vinkel på 180 grader: Agnes ser på ingen måde sig selv som et uforligneligt individ, men vil derimod af med sit særlige »jeg", sit ansigt - hun drømmer om en væren, der er så gennemsigtig og flydende og renset for enhver individualitet, at den minder om døden. Mme Bovarys »anden verden« er en fransk romance-romantik, mens Agnes' er en tysk naturromantik. Det sidste, Mme Bovary ser, er den blindes hæslige ansigt. Det sidste, Agnes ser, er ansigtets eftertragtede opløsning.

\section{Fortællingens veje}

Romanens femte del er efter min mening dens kompositorisk mest virtuose: her kombineres Kunderaplanet og romanpersonplanet, formelle og fortalte bevægelser, narrativitet, tematik og meta-narrativitet i en komposition, hvor fortællende og fortalte forløb, paradigmatiske motiver og syntagmatiske begivenheder løber sammen i klangfulde, omend dissonante akkorder. Her indløser romanen tydeligst den musikalitet, der både i Kunderas og de tidlige romantikeres poetik er et væsenstræk ved romanformen.

Det er også en meget matematisk del, både tematisk og formelt: dens vigtigste figur er den horisontale linie eller kurve, som dog i visse punkter mødes med en vertikal. Den horisontale linie eller kurve manifesterer sig i to motiver: vejen og det narrative forløb (som netop gøres til motiv i diskussionen mellem Kundera og Avenarius). Den vertikale linie manifesterer sig i Saint Germain-kirkens tårn og de diagrammer, Kundera og Avenarius tegner over søsterparret Laura og Agnes. Herved bliver der noget kirketårnsagtigt ved disse diagrammer, som om de to herrer hermed vil rejse katedraler over kvindekroppen. Ved at fremstillle kvindekroppen i samme vertikale dimension som kirketårnets himmelstræben gør teksten den til potentielt sted for transgression, religiøserer den næsten, på en måde som skal vise sig at være en genkommende bevægelse i romanen.

Vejen tematiseres i en forfatterrefleksion (kapitel 3, p. 255), hvor der skelnes mellem to typer af veje. Den danske oversætter har her været i en vanskelig situation, da der ikke på dansk findes hver sin betegnelse for den gammeldags vej, der bugter sig i landskabet og den moderne, der skærer det igennem i en ret linie. Hun har valgt at kalde den gammeldags, bugtede vej for »vejen" og den moderne retlinede for »landevejen«, hvilket imidlertid er problematisk, idet ordet »landevej« har nogle arkaiske konnotationer, som er 
svært forenelige med den moderne retlinethed, det her skal symbolisere. Problemet har været lettere at løse i den franske oversættelse (som Kundera i øvrigt har gennemlæst og tildelt samme autencitetsstatus som den tjekkiske): her skelnes mellem »chemin« (den gammeldags bugtede vej) og "route» (den moderne retlinede). Om de to typer veje hedder det:

"En vej [chemin] er en stribe land, som man går til fods ad. En landevej [route] adskiller sig ikke bare fra en vej [chemin] ved, at man kører i bil ad en landevej [route], men ved at den kun er en linie, der forbinder ét punkt med et andet. En landevej [route] har ingen mening i sig selv; mening har kun de to punkter, den forbinder. En vej [chemin] er en lovprisning af rummet. Hvert vejafsnit har sin egen mening og kalder os til standsning. Landevejen [La route] er en sejrrig ophævelse af rummet, der takket være den, i dag blot er en hindring for menneskelig bevægelse og spild af tid«(p. 255). ${ }^{16}$

Også i Kunderapersonens samtale med Avenarius om romanens narrative forløb tages der afstand fra den rette linie. Således siger Kundera:

"Alligevel beklager jeg, at næsten alle romaner, der nogen sinde er blevet skrevet, er for lydige over for regelen om handlingens enhed. Jeg vil hermed sige, at deres grundlag er en eneste kæde af handlinger og begivenheder, der er årsagsforbundne. Disse romaner ligner en snæver gade, som personerne bliver jaget hen ad med en pisk. [...] En roman skal ikke ligne et cykelløb, men et gæstebud med mange retter.[...] (p. 272).

Vejen er altså ikke bare et motiv på romanperson-planet, men også på romanens ekspliciterede narratologiske metaplan. Herved skydes et ekstra betydningsplan af kompositorisk selvrefleksion ind i hele femte del; begivenhederne på romanpersonernes vej bliver samtidig meget konkrete udtryk for, hvad der sker på romanens egne kompositoriske vej. F.eks. retarderes det narrative forløb mod slutningen af, at Paul, der er på vej for at se sin døende kone en sidste gang på hospitalet, ikke kan starte sin bil (fordi Avenarius har punkteret dens dæk!); denne hindring på Pauls vej er samtidig en højst konkret metafor for det, der sker på det narrative plan: den narrative motor bliver hæmmet! På samme måde konkretiseres Kundera-personens fordring til romanen om at være et "gæstebud med mange retter«i det måltid, han og Avenarius indtager, hvis udsøgte retter beskrives i mundvandsfremkaldende

16. Milan Kundera: L'immortalité, Paris 1990, p.269 
kulinariske detaljer. Mens Agnes dør på motorvejen, nyder hendes eksplicitte fortæller livet sammen med sit dionysiske alter ego; den tragiske død kontrapunkteres af de levende sansers kulinariske tilfredsstillelse; den sørgelige historie af romanens servering af den i små delikate bidder. På denne måde filtres romanens formelle selvrefleksion så uudredeligt ind i dens fortalte personplan, at den i høj grad må siges at leve op til StrohschneiderKohrs' bestemmelse af den romantiske ironi som gestaltningen af det reflekterende fortællerplan efter fiktionens egne principper. Udødelighedens femte del er på én gang »digtning og digtningens digtning« (uden at det ene af disse planer giver køb på det andet) og efterlever hermed den fordring, som Friedrich Schlegel i sit berømte 116. Athenaeum-fragment stiller til »den romantiske digteart».

\section{Koincidenser og sidespor}

Tre historier er på spil i femte del: Historien om Agnes' sidste dag i alpenaturen, hendes ulykke på motorvejen og hendes mand og datters valfart til hendes dødsleje på hospitalet, historien om den miserable selvmorderske, der sætter sig på vejen for at blive kørt over, men i stedet bliver skyld i de afværgende bilisters død - og endelig historien om Kundera og Avenarius, der mødes i motionscentret, stiger ned og går på restaurant, hvorefter Avenarius fortsætter ud i den parisiske nat for at punktere bildæk. De to første historier har i bogstaveligste forstand karakter af veje eller ruter: Agnes' rute fra Schweiz mod Paris, selvmorderskens rute væk fra Paris, men også samtalen mellem Kundera og Avenarius kan metaforisk betragtes som en rute, hvilket en række formuleringer giver anledning til, i hvert fald hvis man holder sig til den franske oversættelse. Her bruges ord som »détourner« og »orienter« til at betegne konversationens forløb (p. 288), og endelig det fatale ord »bifurquer» (p. 295) - fatalt, fordi det netop er en »bifurcation«, der fører Agnes mod hendes død (p. 300). Konversationens metaforiske rute løber over i en bogstavelig, da Kundera og Avenarius siden spadserer i de parisiske gader, og Avenarius fuldfølger denne rute ved at fortsætte alene med sin punkteringsaktion for øje.

Disse tre ruter krydser i løbet af delen ind og ud af hinanden, som telefontråde set i forbifarten. Konversationen er som en støt og bærende melodi, der med mellemrum gennemspiller toner eller motiver fra såvel kommende som tidligere melodier. Omkring den bugter Agnes' melodi sig i en udvikling fra stille harmoni til en stadigt stigende dissonans, der kulminerer, da den mødes med en melodi, som gradvist udskiller sig af konversationen: selvmorderskens melankolske melodi, som stiger til jubel i samme moment, 
som Agnes' stiger til skrig. Derefter diminuendo: konversationens melodi løber ud i Avenarius solo og mødes her et øjeblik med efterspillet til Agnes' melodi: den fortvivlede ægtemand, som fortsætter og indfanger Agnesmotivet en sidste gang: hendes stille og næsten lykkelige død.

De tre planer kobles sammen af det kompositoriske greb der på konversationsplanet tematiseres som »kontrapunktisk koincidens«. I den danske oversættelse bruges ordet »tilfældighed«, men jeg har valgt at løbe risikoen for krukkeri og lægge mig op ad den franske oversættelse med ordet »koincidens«, idet dette ords betydning af sam-begivenhed vitterligt gør det mere præcist (et mere dansk ord ville måske være »sammenfald«).

Selvmorderskens plan vokser gradvist ud af Kundera/Avenarius-planet; det indføres i en koincidensfigur, der ligesom løber løbsk:

"I dette øjeblik [hvor Agnes blev overhalet af tre store motorcykler] bøjede tjeneren sig over vores bord for at hente de tomme tallerkener fra forretten, og jeg var netop $i$ gang med at berette for Avenarius: „Prcecis den morgen, jeg begyndte på tredie del af min roman, hørte jeg i radioen en nyhed, som jeg aldrig vil glemme. En pige var om natten gået ud på landevejen og havde sat sig med ryggen mod den retning, bilerne kom fra $[\ldots] \ll($ p. 270, mine kursiveringer).

I kapitel 17 kolliderer selvmorderskens plan i bogstaveligste forstand med Agnes-planet, således at en begivenhed på personernes vej endnu en gang bliver en meget konkret metafor for, hvad der sker rent narrativt: Agnes og selvmorderskens ruter mødes i en voldsom kollision midt på vejen. Hermed har kompositionen nået sin kulmination i et voldsomt crescendo, og de sidste kapitler er en slags efterspil.

Det, der ser ud til at være et sidespor i konversationen, historien om selvmordersken, som Kundera-personen har hørt i radioen, bliver et fatalt hovedspor i romanen, hvor det fører til Agnes' død. Men sidesporet er ikke bare fatalt på det fortællende plan: det er det også på det fortalte, idet det netop er ved at køre ind på et sidespor, at Agnes kolliderer med selvmordersken - og dør.

Den løbsk-løbne koincidens skaber et sandt kludder i romanens kronologi. Hvis selvmorderskens mord fandt sted natten til "præcis den morgen«, hvor Kundera begyndte at skrive romanens tredie del, kan Agnes ikke køre $\bmod \sin$ af selvmordersken forskyldte død på motorvejen "netop« da Kundera er »i gang med«, i romanens femte del, at berette om selvmordersken. I kapitel 9 er selvmorderskens gerning på Kundera-planet fortid, mens den på Agnes-planet, som postuleres at forløbe samtidigt, er nær fremtid. Hermed fremhæver romanen koincidensen som konstruktion: den lader 
hånt om den realistiske, lineære tid, og er slet og ret et kontrapunktisk kompositionsmiddel.

\section{Tilfældets ulidelige tyngde}

Det bliver den retlinede vej, den af Agnes forhadte - den, der opsluger rummet fremfor at hylde det - , der standser hendes livsbane. Den livsbane, der ellers var på vej til at "sluttes som en ring: fra vejenes verden [le monde des chemins] til landevejenes verden [le monde des routes] og nu tilbage igen« (p. 256). Motorvejens rette linie skærer brutalt igennem Agnes' liv og forhindrer det $\mathrm{i}$ at lukke sig i en cirkel. Vejen, Agnes kører på, bliver ikke den bane, der i en pæn cirkelfigur fører hende tilbage til hendes udgangspunkt, men derimod hendes banesår.

Spørgsmålet er, om Agnes' død ikke også narratologisk set lader den rette linie sejre. Er Agnes ikke en figur, der fra romanens start bevæger sig nødvendigt og sikkert mod sin egen undergang? Er hendes død ikke det forudsigelige mål, historien bevæger sig langsomt, men sikkert mod, lige fra vi møder hende som et (kærlighedsløst) menneske, der er ked ad den moderne verden og kjær ad den hinsides, ansigtsløse? Fortælleren sørger i hvert fald for at flette Agnes' død ind i en kausalkæde, der gør den til alt andet end den »tilfældighed», der har lagt titel til femte del. Det er hverken tilfældigt, at Agnes kommer til at køre på motorvejen i nattemørke, eller at hun drejer af i den frakørsel, der skal føre hende til døden. Hun kommer til at køre i mørke, fordi hun ikke kan få sig selv til at tage afsked med det landskab, der minder hende både om en elsker og hendes døde far. Grænserne melem Agnes, naturen, faderen og elskeren udviskes på en måde, der kan betragtes som intet mindre en incestuøs og nekrofil, og således peger frem mod dødens fuldstændige grænseudviskning. Og da Agnes drejer ad den frakørsel, der skal føre hende til hendes banekvinde, er det fordi, hun ønsker at »undslippe« verden, »undslippe for altid« (p. 285) - en formulering, der nemt kan læses som metafor for et dødsønske. Også den gennem mange år fostrede drøm om at "rejse« (p. 268) har en sådan konnotation af dødslængsel: specielt i den franske oversættelse "s'en aller« (p. 282), som både kan betyde »tage afsted« og "gå bort«. Denne drøm kalder fortælleren en "romantisk drøm«(p. 269) og placerer således her selv sin heltinde i den ellers så foragtede »bande af romantikere«, der længes efter den blånende ikke-væren, efter at "gå bort«.

Agnes' død er således absolut ingen tilfældig, men en - indenfor romanens egen logik - dybt nødvendig begivenhed - netop fordi hun ikke vil tage tilfældigheden på sig. For Agnes er tilfældet ingen »ulidelig lethed«, men en 
"ulidelig tyngde« - en byrde, hun længes efter at kaste fra sig, men som man kun kan blive af med ved at forsage verden og livet. Det er ikke underligt, at Kundera-personen i sin samtale med Avenarius mener, at Udødeligheden egentlig skulle have heddet Tilvorelsens ulidelige lethed, hvis den titel ikke var optaget i forvejen. Agnes deler nemlig langt hen ad vejen problem med denne romans hovedperson, Tomas: også han irriteres over, hvordan hans liv er baseret på det tilfældige, hvordan hans livs kærlighed er en »kvinde født af seks groteske tilfældigheder ${ }^{17}{ }^{17}$ Men Tomas indser efterhånden, at det på paradoksal vis er i tilfældet, at tyngden ligger, mens »det nødvendige« er vægtløst, og modsat Agnes vurderer han tilfældets tyngde positivt. Denne erkendelse skildres meget smukt: Tomas ser i en drøm den "nødvendige« kvinde for sig; den kvinde, der er skabt for ham; den eneste ene, som han må leve sit liv med, men da han vågner og tænker over drømmen, er han klar over, at hvis han virkelig levede sammen med denne "nødvendige« kvinde, og Tereza - den "tilfældige« - gik forbi hans vindue, ville han i hvert øjeblik være parat til at forlade drømmekvinden og følge Tereza. Agnes nægter derimod at tage tilfældigheden på sig: det tilfældige ansigt, den tilfældige gestus, den tilfældige individualitet.

Fortælleren gør altså hvad han kan for at bygge sin Agnes-person op som en dødsstræbende figur, og den dødelige ulykke, der i det virkelige liv ville have været et meningsløst tilfælde, får derved mening og nødvendighed. Netop i romanen bliver det muligt at fremstille en livsbane som nødvendig; i romanen kan tilfældighedens meningsløshed vendes til det konsekvente plots nødvendighed.

\section{Individets billede}

Om forholdet mellem gestus og individ siger fortælleren: »Mange mennesker, få gester« - en formular, der siden også anvendes på forholdet mellem individ og idé (forstået som tanke): »Mange mennesker, få idéer«. Man kan fristes til at anvende samme formular på forfatterens eget værk: »Mange sider - få motiver». Romanen kredser gennem alle sine 400 sider om ét og samme motiv: individets billede. På det eksistentielle plan stiller romanen spørgsmålet: hvad er forholdet mellem det menneskelige individ og det billede af sig selv, det kaster i sin omverden? Findes der et unikt og essentielt udtryk for det enkelte individ? Er individet, det unikke jeg, måske blot en illusion, som ikke mindst romanen med sine velafgrænsede personfigurer er med til at holde i live? Er det menneskelige individ i virkeligheden altid et konstrukt, også når det ikke er en romanperson? På det litterære plan, romanen

17. Milan Kundera: L'insoutenable légèreté de l'être, Paris 1984, p.302 
nødvendigvis hele tiden selv bevæger sig indenfor, bliver problemet om forholdet mellem individ og billede til metaforens problem. Kan litteraturen gennem et billede, en metafor gestalte en individuel essens? Af hvilken art skal en sådan metafor være?

Metaforen tematiseres eksplicit i romanen i den allerede fremhævede samtale mellem Kundera og Avenarius, hvor Kundera - uden større succes forsøger at forklare professoren, at der til hver af hans romanpersoner findes en »Grund«, og at denne grund »har karakter af en metafor» (p. 271).

Hvis man følger Kundera-personens definition af "grunden« som en metafor og iagttager, hvorledes romanpersonernes metaforiske grunde udfoldes i Udødeligheden selv, må man til definitionen tilføje, at en metafor for Kundera tilsyneladende har karakter af et meget visuelt, ofte scenisk, tableau-agtigt billede. Denne tableau-agtighed træder helt eksplicit frem i det sidste kapitel i tredje del, hvor Agnes smider Lauras solbriller på gulvet (som Christiane 200 år tidligere vapper brillerne af Bettina), og fortælleren pludselig leger dramatiker: "Lad os nu forestille os stuen som en teaterscene«, p. 209 og senere: »Lad os ikke slippe scenens helhed med øjnene«, p. 210. Scenen kulminerer i et grammatisk skift fra datid til nutid: »Agnes er i den ene side af rummet med solbrillerne i hånden: i den modsatte side over for hende og langt fra hende som en ubevægelig skulpturgruppe står Laura, trykket ind til Pauls krop. De er begge ubevægelige, som af sten. Først efter et øjebliks forløb fjerner Agnes pegefingeren fra tommelfingeren. Solbrillerne, dette symbol på søsterens sorg, denne metamorfoserede tåre, falder ned på stenfliserne foran kaminen og går itu« (p. 211). Som en flænge gennem tableauets skulpturelle stivnen går Agnes' voldelige bevægelse, hvormed hun ødelægger søsterens symbolske attribut, som samtidig er metaforens metafor. Agnes viser sig i denne destruktive handling endnu en gang som den store metafor-fornægter. Men samtidig viser hendes billedstormerprojekt sig som umuligt: smadringen af de metaforiske solbriller bliver selv en ny, fascinerende metafor. Solbrillernes dobbeltspil vinder alligevel.

Den sceniske »stivnen« til tableau er typisk for de billeder eller metaforer, der med jævne mellemrum skylles i land af romanens flydende prosastrøm. I disse billeder kan Kunderas klare prosa, som er så fuld af forklaringer, af og til krystallisere sig til mystisk forklarelse. De prenter sig i al deres enkelhed ind i læserens bevidsthed og overskrider den intellektuelle reflekteren med al deres plastiske fascinationskraft og deres mangetydige krystallys. Men det er kun på baggrund af den intellektuelt reflekterende prosa, at de kan få lov at stå og lyse - ellers ville de være imagologi.

Mange af disse tableauer (inklusive romanens initiale) beskriver en gestus. Gesten er et af de billeder, hvori romanen gennemgående stiller spørgs- 
målet om individets billede. (De øvrige er: ansigtet, spejlet, kroppe, solbrillerne).

Der er en vis tradition i det moderne vesterlandske åndsliv (det vil endnu en gang sige fra og med romantikken) for at regne det kropslige, gestiske udtryk for et mere oprindeligt og nødvendigt udtryk end det verbalsproglige.

Kundera præsenterer indledningsvis en forestilling om gesten som udtryk for individets essens, men trækker lynhurtigt denne forestilling tilbage: Det er simpelt hen en umulighed, at der i verdenshistorien har eksisteret lige så mange distinkte, unikke gester som individer; det logiske regnestykke kommer til at hedde: »mange mennesker, få gester«, ergo er gesterne overindividuelle størrelser, der gennem historien gentager sig med forskellige individer som deres »redskaber«. Denne tanke kan som nævnt både føre til en op- og en nedvurdering af gesten: Enten må den nedvurderes (som Agnes gør det, da hun opdager sin lillesøster imitere den gestus, hun regnede for sin ejendom) som et tilfældigt og værdiløst attribut, eller også må den opvurderes som en slags overpersonlig, overhistorisk idé. Gesten er altså, som metaforens øvrige figurer, en tvetydig figur: enten tilfældigt attribut eller ophøjet idé.

Lad os se nærmere på den gestus, der først og sidst beskrives i Udødeligheden: den yndefulde, lodrette »bold«-gestus, som Agnes opstår af. Gesten udføres i romanens start af en gammel dame, som Kundera-fortælleren observerer i sit olympiske motionscenter:

"Hun passerede forbi svømmelæreren, og da hun var kommet en tre-fire skridt forbi ham, drejede hun hovedet tilbage mod ham, smilede og vinkede til ham. Og i det øjeblik snørede mit hjerte sig sammen! Dette smil og denne bevægelse [gestus] tilhørte en tyveårig kvinde! Hendes arm steg til vejrs med en bedårende lethed. Det var, som om hun kastede en broget bold op i luften for at spille med sin elsker.[...] En slags essens af hendes ynde blottedes, uafhængig af tiden, i et sekund for mig i denne bevægelse [gestus] og blændede mig. Jeg blev ejendommeligt bevæget. Og jeg kom til at tænke på ordet Agnes. Agnes. Jeg har aldrig kendt en kvinde af dette navn« (pp. 9-10).

Det bevægende ved den gamle dames gestus er ikke mindst dens overvindelse af tiden. I den er ungdommens øjeblik foreviget. Også i et tidligere kropsligt udtryk har den gamle dame ladet et fortidspor komme til syne $\mathrm{i}$ nutiden - da hun ligger prustende i vandet, lyder hun som »et gammelt damplokomotiv«: »(denne idylliske lyd, der i dag er glemt, og som for folk, der ikke har oplevet den, ikke kan beskrives på anden måde end som vejr- 
trækningen hos en ældre dame, der ved kanten af et bassin pruster højlydt ud og ind)«. Her skaber fortælleren en simili-figur, der bider sig selv i halen: den gamle dames åndedræt skal beskrives ved sammenligningen med et damplokomotiv, men dette kan omvendt kun beskrives ved sammenligning med en gammel dames åndedræt... Allerede her er den kiastiske gymnastik altså i gang, som senere skal vende forholdet mellem dame og gestus om, således at det ikke er hende, der udtrykker sig i gesten, men gesten, der udtrykker sig gennem hende. Dette minder om Musils opfattelse af metaforen, som den kommer til udtryk i Manden uden egenskaber, hvor metaforens to termer er reversible: Når man sammenligner en oktobernat med et uldtæppe, er det lige så meget uldtæppet som oktobernatten, man hermed karakteriserer - ingen af sammenligningens termer har noget primat. På samme måde er forholdet mellem individ og gestus: man kan lige så vel sige, at gesten karakteriserer individet, som at individet karakteriserer gesten. Fra starten defineres metaforen altså som et reversibelt forhold mellem to termer fremfor som individets udtrykte udtryk. Romanpersonen og hans/hendes metafor er jævnbyrdige figurer, reversible termer i fiktionens spil: for at forestille os den og den person må vi tænke på det og det billede - og for at forestille os det billede må vi forestille os det levendegjort af den person. Spørgsmålet er lige så vel, om en given metafor formår at udtrykke en romanpersons essens, som om denne romanperson formår at udtrykke metaforens essens.

Af den brogede bolds gestus fødes Agnes. Vi forventer altså nu at se en person udfoldet, som står i et essentielt forhold til denne gestus; at denne gestus skal blive en romanpersons »Grund«; at en person nu skal udfolde sig af denne gestus som en blomst af sin knop. Men fortælleren driller os: først en halvtreds sider inde i bogen oplever vi Agnes udføre gesten, og det viser sig, at hendes "Grund «ikke er denne gestus, men snarere hendes forhold til/ skepsis overfor den: hendes gennemskuelse af dens in-essentielle karakter. Én af metaforens termer har altså vendt sig mod selve metaforens konstruktion; uldtæppet fornægter sin lighed med oktobernatten. Agnes' metafor er ingen metafor, men selve metaforens utilstrækkelighed.

Da romanen første gang lader Agnes udføre gesten (p. 48), kvalificeres den yderligere: den overskrider ikke bare tiden (som vi så det hos den gamle dame), men også ordene, den er ubevidst, og den er formfuldendt som et kunstværk. Der er noget utopisk ved dette modbillede, hvis øjebliks-karakter river det løs af den fortløbende tid i et lysende glimt, så det bliver intet mindre end »mirakuløst«. I et lysende glimt forsøger den bevidste og meget cerebrale prosa at fremmane et billede af et ubevidst og kropsligt sprog, der overskrider den selv. Den gestus, fortælleren på sin side foretager med billedet, er altså en gestus, der længselsfuldt strækker sig ud over værket, mod et 
helt andet sprog; hans arm strækkes i vejret for at kaste det kropslige og bevidsthedsperforerende sprogs gyldne bold ud over værkets grænser.

Omgærdet af utopi er bold-gesten i hvert fald, da Agnes ser den udført af faderens sekretær som en afskedshilsen (hvoraf hendes egen senere gestus er en ubevidst imitation):

»Engang da damen var på vej fra huset ned mod lågen (hun gik altså i præcis den modsatte retning af den, Agnes noget senere skulle gå, fulgt af den ulykkelige skolekammerats blik), vendte hun sig, smilede og kastede armen op i luften med en uventet bevægelse, let og glidende. Det var uforglemmeligt: den grusbestrøede havegang glitrede i solstrålerne som et gyldent vandløb, og på hver side af lågen blomstrede en jasminbusk. Det var, som om den opadrettede bevægelse ville vise dette gyldne stykke jord, i hvilken retning det skulle stige til vejrs, og de hvide jasminbuske var allerede begyndt at blive til vinger« (p. 48).

Her understreges gestens vertikale himmelstræben, den giver jasminbuskene englevinger og indikerer intet mindre end retningen for den gyldne jords himmelflugt. Den gør øjeblikket uforglemmeligt og ser hermed ud til at have nogle kvaliteter til fælles med poesien, om hvilken det andetsteds hedder, at den gør »ét øjeblik uforglemmeligt og værdigt til uudholdelig længsel« (p.36). Det »formfuldendte kunstværk«, gesten i forrige citat blev sammenlignet med, har altså sandsynligvis karakter af et digt. Hermed kvalificeres det udtryk, prosaen længes efter i gestens billede, endvidere som poetisk. ${ }^{18}$ I gesten og poesien kan øjeblikket foreviges, eller udødeliggøres om man vil; den eneste antydelse af en sand udødelighed, man finder i Udødeligheden, er gestens og poesiens. Men selv er Udødeligheden en roman: dens formfuldendthed er ikke poesiens øjebliks-koncentrat, men prosaens tidslige udfoldelse. Den lader ikke gestens billede stå som et vertikalt og koncentreret digt, men vælter det ud i horisontaliteten, folder det ud i en episk tidsstrøm, hvor det rejser sig som punktuelle milepæle, der kan forbinde fjerne tider med hinanden. Den skaber herved lige så vel som gesten og poesien en tidslig overskridelse, blot ikke ved at koncentrere øjeblikket, hive det ud af tiden, men ved at lade det være et punkt, der gentages i tiden og således slår bro over store kronologiske afstande.

Gesten bliver som gennemgående motiv i Udødeligheden netop brugt til at skabe forbindelse mellem to forskellige epoker, der ikke bare er adskilt ved 25, men ved næsten 200 år: det tidlige 1800-tal i Goethes Tyskland og det

18. Slægtskabet mellem gesten og poesien påpeges også af Isak Winkel Holm i artiklen »Gestus og roman«, Den Blå Port 14 (1991). 
sene 1900-tal i Kunderas Paris. F.eks. udfører Bettina von Arnim og Laura samme "gestus af længsel efter udødeligheden«, Agnes og Goethes kone Christiane fejer med samme vrede gestus hhv. Lauras og Bettinas briller på gulvet, og Goethe og Rubens udfører samme mekaniske forførergestus, da de lægger hånden på hhv. Bettinas og Agnes' bryst. Man kunne med et begreb fra Walter Benjamin sige, at gesten som motivisk figur etablerer et stereoskop, som viser Goethe-Tyskland i den ene linse og det nutidige Paris i den anden. Fortidens gester lever videre i nutiden. $\mathrm{Og}$ af og til kan de ligefrem se ud til på benjaminsk-stereoskopisk vis at minde nutiden om fortidens uindløste forventning. I hvert fald bliver bold-gesten i et enkelt tilfælde ganske eksplicit en sådan påmindelse. Da Agnes sidder på café med Laura, som beretter om sine selvmordsplaner, bryder der pludselig en latter løs mellem de to søstre, så afstanden mellem dem smelter bort, og frem bag denne latter bryder billedet af den gamle gestus, der nu beskrives således:

»en bevægelse [gestus] af en hånd, der kastedes i vejret som en broget bold, som en opfordring til rejse, som et løfte, der talte om en uanet fremtid, et løfte, der ganske vist ikke var blevet opfyldt, men alligevel var hos dem som et smukt ekko«(p.186)

Her bliver gesten til »ekkoet af et løfte«, til det, der bærer fortidens forventning med ind i nutiden, gør nutiden opmærksom på, at den engang var en »uanet fremtid«, fuld af muligheder - og det er den måske endnu!

Bemærk, at der i beskrivelsen af gesten (i forhold til s.9 og s.47-48) er sket en forskydning i forholdet mellem hånd og bold: hånden sammenlignes nu med selve bolden og ikke med den hånd, der kaster den. Der er sat parantes om den kastende hånd, om mani-pulatøren; gesten (eller metaforen) kan svæve af sig selv, har løsrevet sig fra den styrende hånd. Måske har også fortælleren på dette sted mistet håndens styring (måske er håndens forsvinden ligefrem en lapsus fra hans side...); i hvert fald bryder den symmetriske modsætning mellem de to søstre, som han så konsekvent har opbygget, her sammen; den gestus, de forholder sig helt modsat til (Agnes vil »trække den fra» sit jeg, Laura vil »lægge den til«), markerer her ikke længere en forskel mellem de to kvinder, men et fællesskab. Det er som om, hele fortællingens stramme struktur - dens tematiske geometri såvel som dens narrative fatalitet - her tager en pause, kaster sine skarpe modsætningspoler, Agnes og Laura, grinende i armene på hinanden og siger: det hele kunne være anderledes (eller som det hedder på tysk, med et af Kunderas yndlingscitater fra Musil: »es könnte auch anders sein«), ligesom også gestens påmindelse om fortidens forventning rummer et sådant udsagn om mulighedens mægtighed. 
Bold-gesten bliver her til selve løftets form, til selve den bevægelse, i hvilket al et øjebliks forventning kastes ud i fremtiden, og som i erindringen bliver en påmindelse om at gribe den bold, der blev udkastet af fortidens løfter, og sende den videre. På fortællingens formelle plan er det jo også lige præcis det, der sker: fortællingen griber igen fat i sin initiale figur, husker sit løfte om at lade den være sin »Grund «og sender den videre i forløbet med en ny betydning af erindringsfødt håb.

Da gesten udføres allersidste gang i romanen, er det af Paul. Og her kvalificeres den med endnu et attribut, som hidtil har været implicit, fordi den ellers altid er blevet udført af kvinder: den er feminin. I sin hyldest til kvinden knytter Paul endvidere det feminine sammen med det, som gesten også repræsenterer: håbet eller forjættelsen. Kvinden er mandens fremtid, hævder Paul, for »kun kvinden er i stand til at nære et ubegrundet håb i sig og kalde os ud i en tvivlsom fremtid« (p. 389). Gesten, der har repræsenteret prosaens drøm om at blive poesi og verbalitetens drøm om at blive krop, bliver hermed udtryk for endnu en drøm: mandens drøm om at blive kvinde.

Og i fortællerens ironiske perspektiv bliver Paul faktisk til kvinde, i en vrangopfyldelse af hans egen utopi: for »Kundera«s øjne på én gang ældes og feminiseres Pauls ansigt på helt grotesk vis:

»Jeg syntes, at han pludselig ældedes. Hans vældige grå manke forvandledes pludselig til frisuren på en gammel dame...Nu var han allerede halvfjerds og straks efter firs...Han vendte sig skiftevis mod alle sine ansigter i spejlene og talte med en gammel dames svage høje stemme...» (pp.385-386).

I denne groteske transformation opfyldes Pauls utopi om det kvindelige på den måde, Avenarius hånligt vælger at forstå den: »Hvad skal det sige, at kvinden er mandens fremtid? At mænd forvandles til kvinder?« (p. 386) Ja, Paul forvandles til kvinde, til en gammel tandløs kælling, kastreret som han er af Lauras løfte til Avenarius om utroskab.

I denne sidste gennemspilning af boldgesten skal den altså latterliggøres. Men netop denne ironisering af boldgesten er måske nødvendig for at bevare den. På den ene side latterliggøres Pauls utopi om det kvindelige af hans naive uvidenhed - på den anden side fastholdes den utopiske gestus som kvindelig i kraft af latterliggørelsen af Paul, hvis ubehjælpelige vinken beskrives som »en kejtet, maskulin efterligning af den smukke feminine bevægelse [gestus]«(p. 390).

Man kunne også sige: der findes to slags ironi i den afsluttende beskrivelse af Paul og gesten. Der findes den latterliggørende ironi, som opstår i diskrepansen mellem fortællerens udsigelsesniveau og Pauls, deres forskellige 
positioner i udsigelseshierarkiet. Og så findes der en ironi som er en svæven mellem flere mulige, men ikke hierarkisk ordnede perspektiver.

\section{Ironi}

I Romankunsten definerer Kundera selv romanens »konsubstantielle« ironi som en fundamental tvetydighed, en konsekvent svæven, der ikke tillader nogen stivnen i faste værdi- eller moraldomme. Således mener han (p.163, under »IRONIE«), at de forskere, som skændes om, hvorvidt f.eks. Werther eller Madame Bovary er latterlige eller ophøjede, fuldstændig har misforstået romanens univers, som i sin fundamentale ironi modarbejder enhver éntydig dom.

Givet er det, at Udødeligheden selv lader sine gennemgående figurer og personer svæve i tvetydighed. Figurerne: Gesten, kroppen og ansigtet har snart status af idéer, der overskrider det enkelte jeg, snart af attributter, som puster jeg-illusionen op. Personerne: Ganske som Madame Bovary både er en idealistisk drømmer og en dum gås, bader Udødeligheden de fleste af sine personer i både sym- og antipatiens lys. Selv Agnes, der er romanens store heltinde og som påvist står fortælleren nær, kan, hvis man forfølger visse tekstspor, læses som en kærlighedsløs dødsstræber. På samme måde kan romanen glimtvis vise os sin anden store helt, Goethe, som en forfængelig gammel nar (pp. 84 og 233), og omvendt kan de overvejende antipatisk skildrede personer: Paul, Laura, Bettina pludselig lyse med et rørende skær, som blødgør det læsende øje.

Det reflekterende - og som påvist olympisk situerede - fortællerplan skaber en ironisk distance mellem fortællerens perspektiv og de demonstrativt konstruerede romanpersoners. Men en sådan ironi er ikke identisk med det, Kundera i Romankunsten kalder romanens »konsubstantielle« ironi. (De romaner, MK selv nævner under sin ironi-definition, Mme Bovary og Den unge Werther, har da heller ikke et sådant ekspliciteret forfatterrefleksionsplan). Den konsubstantielle ironi bæres ikke bare af distance til fiktionen, men i lige så høj grad af nærhed; af en svæven mellem sød henfaldelse til fiktionens billeder og personer og kølig afstandtagen herfra.

Den konsubstantielle ironi (den som altså ifølge Kunderas egen definition er den ægte roman-ironi) ser jeg som en dobbelt optik i romanen. Denne dobbelte optik etableres bl.a. gennem Avenarius-personen, der pendler mellem Kunderas og romanpersonernes plan. ${ }^{19}$ Alene i kraft af denne pend-

19. I et interview i Le Monde 24.09.93 kalder Kundera Avenarius "mon personnage le plus aimé«. 
len bliver han en slags svævefigur, der snart befinder sig på fortællerens distanceplan, snart helt tæt på de øvrige fortalte personer. Han er en slags alter ego til Kundera-personen, en handlingens og nydelsens mand med en potens, Kundera ikke kan hamle op med («jeg er ikke udrustet som du«, p. 278); en prustende Dionysos, som går i klinch med modernitetens dårligdomme (sammenfattet i begrebet »Diabolos«) og romanpersonerne fremfor at reflektere over eller lægge afstand til dem. Hans perspektiv på Agnes, Paul og Laura går imod Kundera, som feterer Agnes og behandler Laura og Paul med den krasseste distance-ironi. Avenarius foretrækker derimod Laura for Agnes (p. 276) og »holder oprigtigt af« Paul (p. 391).

Men også uden Avenarius' formidling kan teksten pludselig nærme sig de personer, den ellers distancerer sig fra. Den naive, sentimentale Paul, som mere end Rimbauds digte tilbeder hans fordring om "absolut modernitet», som forguder sin unge og hjernetomme datter (bogens krasseste karikatur!), som hører hjemme i »le monde des routes«, og som i bogens sidste kapitel celebrerer sit eget 27 gange genspejlede ansigt - denne naragtige fyr bevæger sig i et enkelt kapitel på et udsigelsesniveau, der er helt parallelt med fortællerens! Det drejer sig om 7. kapitel i romanens 3. del, som er en refleksion over »imagologien« - et kunderask begreb for vort nuværende kulturstade, hvor billederne har afløst idéerne, plakater og reklamer ideologierne. Kapitlet begynder som en almindelig forfatterrefleksion, som hører hjemme på fortællernes udsigelsesniveau, men pludselig hiver fortælleren Paul op på sit niveau: „Imagologi! Hvem fandt først på denne ypperlige neologisme? Jeg eller Paul?«(p.134). Sagt med Pauls ord: »Ideologierne tilhørte historien, mens imagologiens herredømme begynder, hvor historien ender« (p.136.)

Her brydes den overvejende distance mellem fortællerens og Pauls perspektiver af en nærhed, ja næsten en sammensmeltning.

\section{Tableauets poetiske forklarelse}

I forhold til de to kvinder, der på tværs af historien har meget til fælles, Bettina von Arnim og Laura, brydes fortællerens distance ikke så meget udsigelsesmæssigt som af den poetiske forklarelse, der dæmrer, når fortællingen glimtvis stivner til tableau. Også Bettina og Laura forklares nemlig glimtvis i sådanne tableauer, hvor en overpersonlig skønhed bryder frem om disse sentimentale hystader, som ellers blot har travlt med at indskovle attributter til deres store og illusoriske egoer.

Endelig udsættes også Agnes for den dobbelte optik. Det er allerede påvist, hvordan Agnes på forskellig vis tilnærmes fortællerens position og således bliver den person, der står ham nærmest, og hvis død man må 
begræde. Men samtidig objektiveres i teksten en struktur, som jeg også har påvist, der gør Agnes til en kærlighedsløs og næsten fej person, der må dø med nødvendighed. Det er således tvetydigt, om Agnes er en hellig kitschfornægter eller en fej dødsstræber. Også på anden vis udsættes hun for en dobbelt optik: i sjette del forekommer det mærkværdige perspektivskift, hvor ansigtsfornægteren Agnes betragtes fra en helt ny vinkel, nemlig Rubens', hvorfra hendes ansigt tager sig enestående ud. (At ansigtfornægteren Agnes' ansigt slutteligt bliver så vigtigt for en anden person kan om noget kaldes ironisk!)

Rubens bliver bærer af synsvinklen i en række fascinerende, mytiske billeder af Agnes. Lad os se på det sidste billede i denne billedserie; et billede hvori romanen virkelig forsøger at træde ud af sig selv:

»Han var igen i Rom. På museet opholdt han sig længe i salen med gotiske billeder. Foran et af dem blev han stående fascineret. Det var korsfæstelsen. Hvad så han? Han så i Jesu sted en kvinde, som man netop var ved at korsfæste. Som Kristus havde hun ikke andet på end et hvidt klæde, viklet om hofterne. Hun støttede fødderne mod et træfremspring, mens bødlerne fæstnede hendes ankler til bjælken med tykke bånd. Korset var rejst på toppen af en bakke og kunne ses fra nær og fjern. Omkring det var horder af soldater, mænd og kvinder af folket, nysgerrige, alle kiggede de på kvinden, der var udstillet for deres blikke. Det var lutspillersken. Hun følte disse blikke på sin krop og dækkede sine bryster med hænderne. På hendes venstre og højre side var rejst to andre kors, og til hvert af dem var bundet en røver. Den første bøjede sig over mod hende, tog hendes hånd, rev den væk fra hendes bryst og strakte hendes arm ud, så hendes håndflade berørte enden af korsets vandrette arm. Den anden røver greb hendes anden hånd og foretog den samme bevægelse, så lutspillersken havde begge arme udstrakt. Hendes ansigt forblev bestandigt lige ubevægeligt. Hendes øjne var rettet ud i det fjerne. Men Rubens vidste, at hun ikke så ud i det fjerne, men ind i et kæmpemæssigt imaginært spejl, anbragt foran hende mellem himmel og jord. Hun så i det sit eget billede, billedet af kvinden på korset med udstrakte arme og blottede bryster. Hun var udstillet for den umådelige, skrigende, dyriske hob, og kiggede ophidset på sig selv sammen med dem«(p. 369).

Læst på én måde, som seksuel fantasi, er »visionen« nærmest en parodi, på en halvsadistisk forførers forestillinger om en optimal kvindelig masochisme, forklædt i kunstens skønne slør og kristen mystik. I så fald ironiseres Rubens' perspektiv. Men billedet (og dermed Rubens' perspektiv) kan lige så 
vel tages alvorligt; det bliver da en smuk og mystisk allegori, en forklarelse af Agnes, en kulmination på den jagt efter Agnes' »Grund «, som startede med bold-gestens billede. Et belæg for at læse billedet som en »Grund «for Agnes, er, at hendes navn her udfolder sin egentlige betydning. Agnes betyder jo »lam«, og hængende på korset bliver Agnes netop til »lammet«, symbolet på den korsfæstede Jesus. Endvidere er Agnes, som Jesus, knyttet til sin far i himlen, ja længes egentlig kun efter at komme til ham, gennem sin egen død. I kraft af at hun er en romanperson, deler Agnes også den skæbne med Jesus, at hun er ordet, som er blevet kød - og dette kød skal nu ofres.

Den korsfæstede kvindes blik i det fjerne får én til at tænke på Bettina von Arnims bevægelse ud mod horisontens absolutte. Det, der stråler mod Agnes fra horisonten, er imidlertid ikke, som for Bettina, "verdens absolutte«, men hendes eget spejlbillede. Det, der møder det moderne menneske i det absoluttes horisont, er jeg'ets eget billede; det er det, der har fået absolut status i den moderne kultur. Men dette jeg-billede udmærker sig for Agnes' ved at være kroppens billede, og som sådant ser jeg-billedet ud til at rumme en mulighed for jeg-overskridelse. Jesus på korset er da også om noget et billede på en overskridelse, der går gennem kroppen; på kødet, der overskrider sig selv ved for alvor at gå ind i sin kødelighed, i sin kødelige smerte.

Med korsfæstelsens billede forklares Agnes pludselig i et billede af mytisk offerdød; en død, der slår om i genopstandelse; den død, der indenfor den kristne mytologi frelser menneskeheden, skænker menneskesjælen dens udødelighed. I denne mystiske og blændende forklarelse af Agnes som martyr, ja som intet mindre end en kvindelig Jesus, overskrider romanen sig selv, overskrider sin egen kontrollerede intellektuelle konstruktion og går ind i det mystiske billede, som endog er selve overskridelsens billede: billedet af den korsfæstede, som overskrider tærsklen mellem kød og ånd, menneske og Gud, levende og død. Overskridelsens sted er den nøgne kvindekrop, det er dens billede, der forbinder »himmel og jord «. Agnes' korsfæstede krop blænder med et lys, der er lige så kraftigt som håbets stjernes i Goethes Wahlverwandtschaften. Kødet har nået sin hellige ophøjelse, sin apoteose, Agnes er kommet hjem til sit navn - hun er blevet til lammet, Guds hellige offerlam.

Indførelsen af et helt nyt perspektiv på falderebet er på én gang en ironisering og en åbning. Det ironiske ligger i, at Agnes i Rubens' perspektiv får det ansigt, bliver det individ, stivner til det billede, hun i resten af romanen - under opbakning fra fortælleren - har forkastet. Det er sikkert mest i Kunderas ånd at læse dette som en beklagende påpegelse af, at man aldrig er herre over sit eget billede, at selv det mest tilfældige og perifere møde kan gøre én til "nogen« i en anden persons øjne. Således har den aldrende Hr. 
Kundera selv haft travlt med at redde sit billede for eftertiden, sådan som hans essaysamling De forrådte testamenter vidner om det. Her forsøger han at sikre sig mod andre menneskers billeder af ham og hans værk, som han erklærer, at kun han selv kan forstå. Ảbenbart er han meget bange for den dag, han ikke længere er her til at sige de falske billeder imod; for ham er døden først og fremmest et skræmmende tab af kontrol over sit eget billede, ganske som Agnes i sit overvejende fravær, der slutteligt radikaliseres til død, ingen kontrol har over Rubens' billeder af hende. På den anden side er der en vis solidaritet mellem den øvrige romans fortæller og Rubens; deres Agnes-billeder er på flere måder beslægtede, så det er umuligt at læse Rubens' perspektiv som helt tilfældigt og misforstående. Fra dette synspunkt er Rubens' perspektiv ikke så meget en ironisering som en ophøjelse af Agnes. Og da bliver skiftet til hans perspektiv selve romanens ironiske selvoverskridelse, den forskydning, der skal til, for at Agnes-figuren kan begynde at lyse. Som om perspektivskiftet fra Agnes' solidariske skaber til hendes fascinerede medskabning er nødvendigt, for at romanens rationelle diskurs for alvor skal overskride sig selv og blive mystisk.

Billedet af den korsfæstede Agnes er for mig at se bogens kulmination, det mest overskridende af de tableauer, hvormed den hele tiden overskrider sin egen rationelle diskurs. Og overskridelsen er også voldsomt til stede på motivplanet, idet den korsfæstede Kristus jo er selve overskridelsens billede. At overskridelsens sted er kvindekroppen er et i romanen gennemgående motiv, som her radikaliseres i den grad, at det mest transgressive af alle legemer i vor kultur, Jesu pinte legeme på korset, udskiftes med en kvindekrop. Her fuldføres altså det kønsskifte fra mandligt til kvindeligt, som er en af de selvoverskridelser, romanen drømmer om i den gennemgående boldgestus. Men vigtigt er det, at dette mystiske, højtidelige billede er pakket ind i ironi; det svæver ironisk mellem virkelig at være mystisk vision og at være en donjuanistisk fantasi om en vældig kvindelig masochisme. Og den kønstransformation, billedet så mystisk foretager, parodieres i den efterfølgende 7. del i Pauls bliven til gammel kvinde, hvor der langtfra er tale om mystisk ophøjelse, men derimod om latterliggørelse og (symbolsk) kastration. På den måde udviser billedet virkelig den adfærd, som både er ironiens og metaforens: det sættes frem og trækkes tilbage, er både en afsløring (af Agnes' krop såvel som af romanens drøm om den transgressive kvindekrop) og en tilsløring (Agnes har skjult sig bag sit billede). Rubens' forsøg på at indfange Agnes (ikke mindst hendes nøgne krop) i en billedserie kan altså enten anklages feministisk for at være indskrænket donjuanisme - eller forstås som ironiens reddende bevægelse over for det mystiske billede, der ellers ville drukne i imagologiens altoversvømmende kitschflod. Også tvetydigheden selv er tvetydig: der findes en »kitschy« tvetydighed (tematiseret i 
kapitlet »mangetydigheden« i tredie del), der hører hjemme i en imagologisk erotisme (som Rubens tildels repræsenterer) - og så findes der ironiens dybe tvetydighed, som gør det muligt at redde visse billeder fra imagologiens altindoptagende strøm.

Med Rubens-delen introducerer Udødeligheden overraskende et nyt perspektiv på falderebet. Hermed fuldender den sig gennem selvoverskridelse. Det er i denne formfuldendte gåen ud af sig selv, at romanen lader læseren træde ud af dens virtuelle tryllekreds, udkaster romangenrens vigtigste budskab: »es könnte auch anders sein«, lader forjættelsen hænge som en gylden bold over romanens udgang, angiver en vej ud af sine egne strukturelle bindinger, så de ikke bliver tunge som myter. 